\author{
Mariusz Korzeń \\ mgr inż. \\ absolwent Politechniki Wrocławskiej \\ Wydział Budownictwa Lądowego i Wodnego \\ mariuszkorzen9@gmail.com
}

\title{
Concept of cross - city rail route in Wroclaw to create the LRT system
}

\begin{abstract}
The article presents a proposal for the construction of a cross-city rail route in Wrockaw in order to create a LRT system. The main motivation for the creation of the LRT system is the constantly growing traffic towards the center caused by the increasing number of people living in the peripheral parts of the city and neighboring municipalities making up the Wrocław agglomeration. As an example of an efficient LRT system using a cross-city tunel is the S-Bahn system in Munich was cited, in which the railway tunnel running through the city center determines large flows of passengers and is therefore one of the main means of transport in the entire agglomeration. In the next part, the current state of the Wrockaw Railway Junction is briefly discussed, thus showing the city's great potential to create the LRT system. Places where direct access to the railway network should be provided have been indicated. It was proposed to create two cross-diameter routes running entirely from the tunnel. Their course should be dictated by the location of the traffic generators indicated in the article in the center of Wrocław. In the summary, the author presents the benefits of building new routes and mentions the need for the development of the rail transport network resulting from the Wrocław Mobility Policy. The creation of a new route running through the city center would significantly increase the transport attractiveness of the railways, and thus, the new route would be a key element for the creation of an efficiently functioning LRT system in the city and the entire Wrocław agglomeration.
\end{abstract}

Keywords: Railway tunel; Cross - city route; Agglomeration railway; Wrocław

\section{Introduction}

The problem of transport in cities (mainly public transport here) has been known to people for centuries, although it intensified with the industrial revolution of the 19th century. Along with the development of cities, the demand for transport grew, and thus the problem of transport also grew, which in turn was associated with the need to introduce changes for the further efficient functioning of the city. The problem was particularly acute in the densely built-up city center, which was (and still is) the most common travel destination. Depending on the size of the city and its potential (mainly economic) opportunities, specific measures are introduced to effectively solve the problem of transport in the city. The best solution is to build an underground rail network that is able to transport a large number of people in a relatively short time in a collision-free manner. Consequently, metro networks have been created in many cities to improve the transportation of people in the city.

Currently, one of the solutions is to use the existing railway network, thus creating the LRT system. However, in order to increase its attractiveness for transport, a new cross-city route is being built, which enables quick travel from peripheral directions to the center, without the need for a change. This is the case, for example, in many German cities such as Leipzig, Munich and Stuttgart, where a tunnel was added to extend the existing headend and is often located right next to the city center. The new section of the line is the so-called "Stammstrecke" or the main route on the network where the vast majority of lines converge, which therefore makes this mode of transport very attractive. 
The problem of transport can still be felt in Wrocław, and it concerns not only the city itself but the entire Wrocław agglomeration. During rush hours on the main communication arteries, traffic jams are common, and urban transport does not always offer convenient travel times. According to the author of the article, the introduction of an efficiently functioning LRT system, running through the very center of the city, will significantly solve this problem, as well as encourage residents to change their ways of traveling and choose a greener means of transport, which is the rail.

\section{An example of the S-Bahn network in Munich}

Due to the appropriate optimization of the network, the assumed daily flows of passengers at the level of PLN 250,000 significantly exceeded the assumed value and currently amount to over PLN 840,000 during the day [8]. Due to the fact that the capacity of the cross-city section was exceeded and the constantly growing passenger flows, it was decided to build a second cross-city route parallel to the already created line (the so-called Zweite Stammstrecke). The approx. $10 \mathrm{~km}$ route will run between Laim in the west and Leuchtenbergring in the east. The key element for the investment will be a seven-kilometer long tunnel connecting the Main Railway Station with the Eastern Railway Station. The planned route of the new route against the background of the existing one is shown in Figure 1. The existing sections are marked in green and the newly designed route is in red. The sections in the tunnel are marked with a dashed line. Currently, the network is constantly expanded to ensure the best possible transport offer [7].

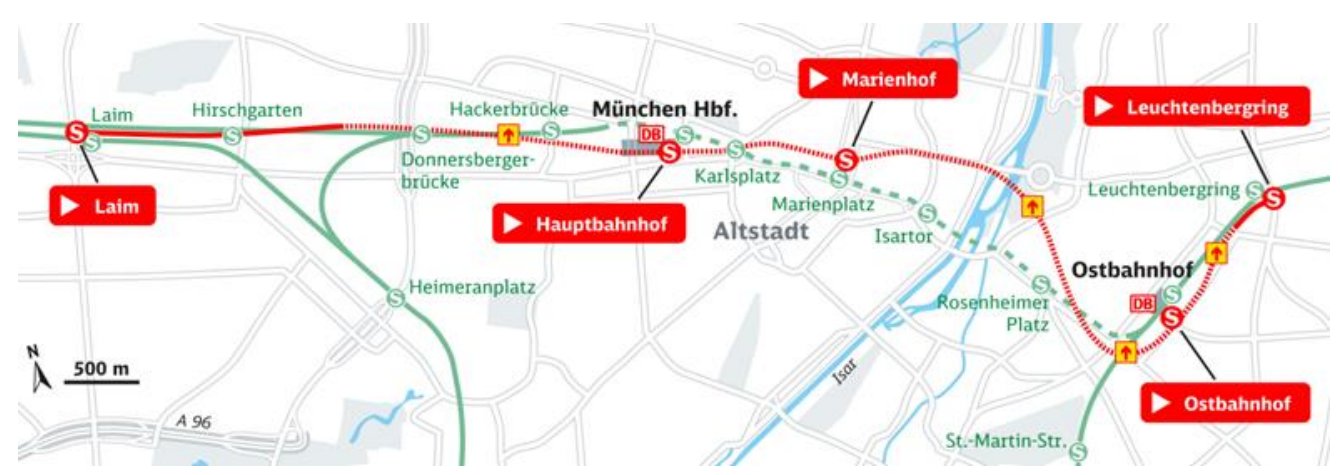

1. Planned route of the second main railway line in Munich

Source: [7]

\section{WWK existing condition}

The Wrocław Railway Junction (WWK), due to its long history, is one of the most developed railway junctions in Poland. In total, lines from ten different directions converge in Wrocław, as shown in Figure 2. Lines that are not currently used linearly and lines intended for freight traffic are also marked. It is clearly visible that the node covers most of the city, but at the same time, it also circles the city center. This shows the great potential of the city and the agglomeration to create the LRT system. Unfortunately, in the current system, the network circles the city center, which makes the railway lost its transport attractiveness. The cross-city section is a 3-track section of the network from the Grabiszyn branch post to the Wrockaw Główny station. It is completely collision-free with other means of transport, it runs partly in the embankment and partly on the flyover. The section is used by regional and long-distance passenger trains going from seven different directions. The research conducted in January 2021 shows that during rush hours, trains pass through the cross-city section approximately every 2.5 minutes [2]. The introduction of additional LRT trains may cause major difficulties in the overlap of the capacity of the cross-city section. Therefore, the construction of a new 
route should be considered, taking into account places that are a frequent destination of residents, later referred to as traffic generators.

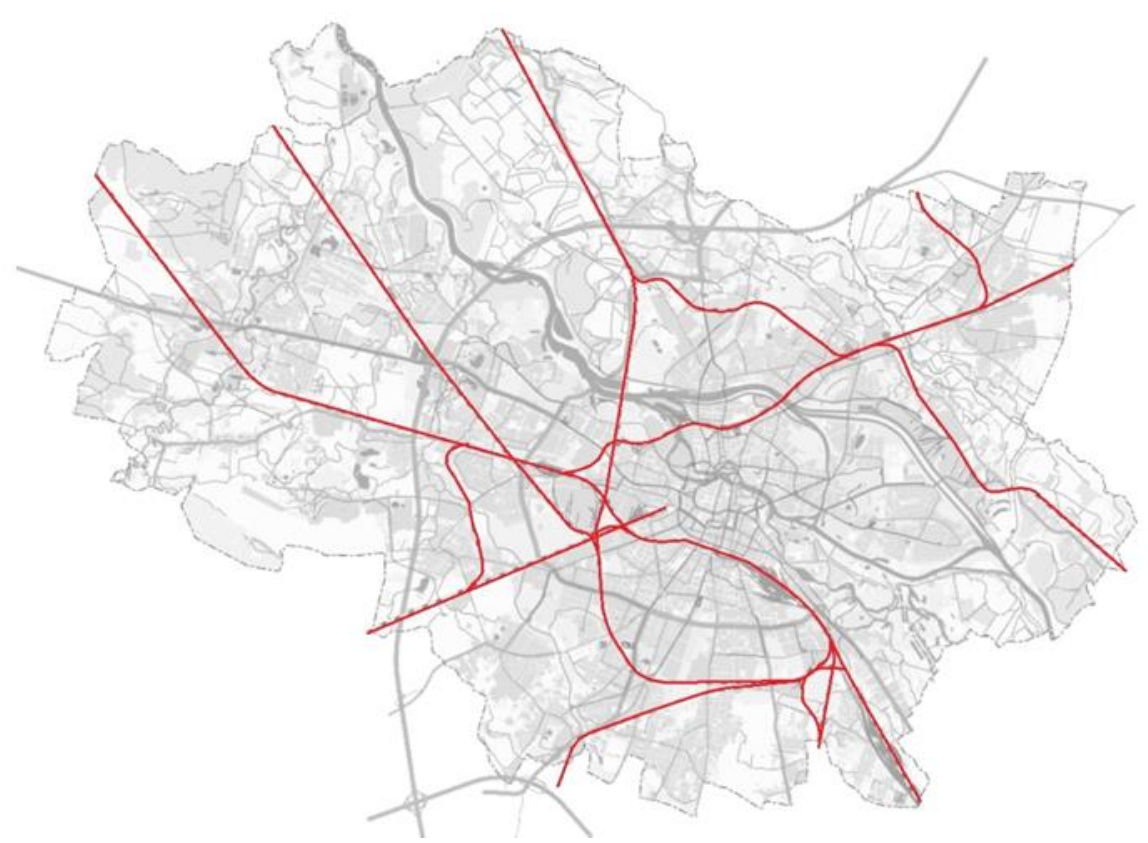

2. Wroclaw Railway Junction on the city map, source: own study Source: own study based on [9]

\section{Traffic generators in the city}

The places on the city plan that are the most frequent travel destination were considered to be traffic generators, and therefore the streams of passengers are the largest in these places. Such places in Wrocław include, among others:

- Main Railway Station / Bus Station - a transfer node between various means of transport (urban, regional, long-distance transport),

- Old Town / Market Square - an area generating a lot of tourist traffic,

- Dominikański Square - a large transfer junction in the Old Town,

- Bema Square - a transfer junction towards the northern part of the city,

- Grunwaldzki Square - one of the most important transfer junctions in the city. A large academic center in the vicinity, access to practically every part of the city from the square,

- John Paul II Square - an important transfer junction towards the western parts of the city,

- Hala Stulecia / ZOO - places generating high tourist traffic,

- Crossroads at Arkady Wrocławskie - a transfer junction towards the southern part of the city,

and in the near future it may also be:

- Świebodzki Railway Station - it is possible to develop the area next to the station, creating a new center of Wrocław [1],

- Social Square - according to the Local Area Development Plan, the target square is to be developed in the future and create an important point on the city map [10],

- the so-called Wielka Wyspa Aleja ("Great Island Avenue", in progress) - a new investment in the eastern part of the Wrocław downtown bypass. The new route will enable the creation of a new transfer junction within Biskupin and Sępolno. 
The location of the above areas against the WWK background is shown in Figure 3. As can be seen in the figure, the generators are located mainly in Śródmieście, which means they are outside the direct influence of the railway network. Launching the LRT system, without building a new cross-city route, will significantly reduce its attractiveness because access to the destination will require a change.

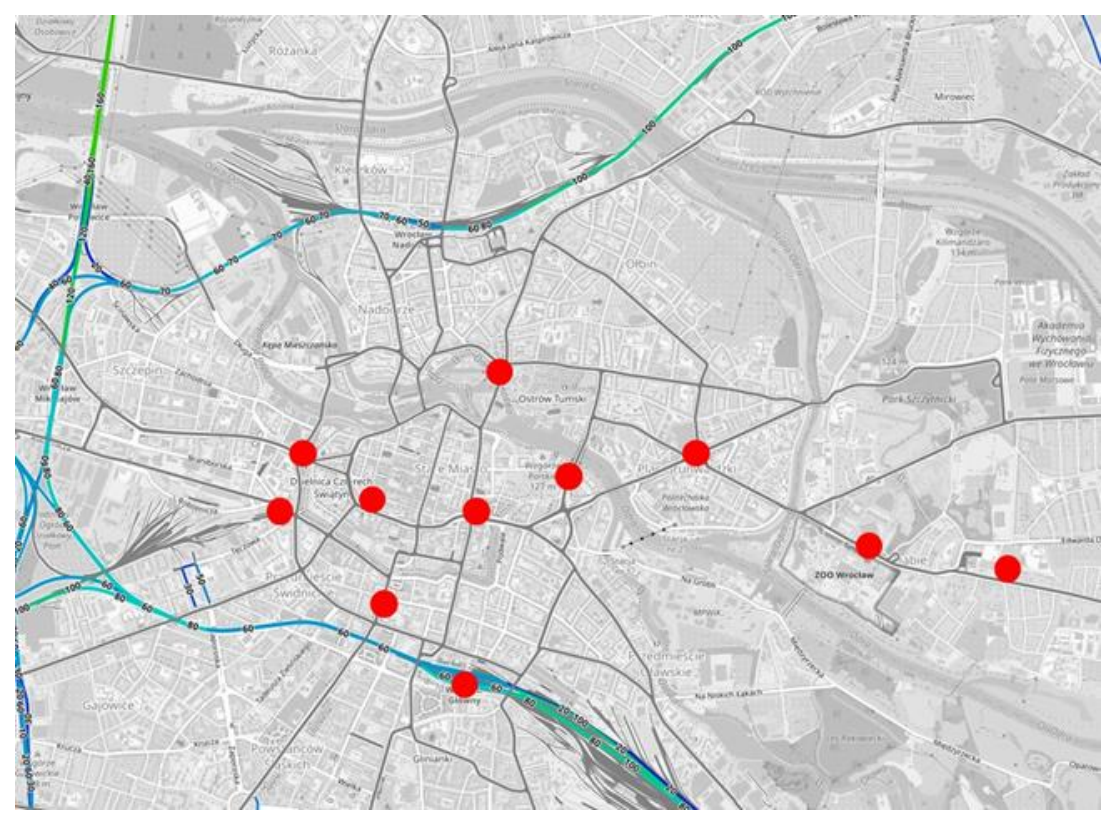

3. Distribution of traffic generators in relation to the Wrocław Railway Junction Source: own study based on [4]

\section{The course of a new route}

When designing a new route, it is first of all necessary to take into account the largest possible number of the aforementioned traffic generators (including the future ones) in order to maximize the transport potential of the future LRT system. Due to the dense downtown buildings, new routes in the tunnel were to be built in the center. A total of two new sections of a cross-city route were proposed. The first tunnel will connect the Świebodzki Railway Station and the Wrocław Swojczyce station. Its course has been planned through the Old Town, Sródmieście and the Great Island. It is planned to create 8 new underground stops on the route. The second tunnel will connect the Swiebodzki Railway Station with the Wrocław Główny station. The connection of both stations will ensure more convenient transfers from LRT trains to regional or long-distance trains. It is planned to create three new underground stops along the route. The routes of individual tunnels and the location of the new stops are shown in Figure 4. Świebodzki Station is the place where both tunnels begin, therefore it will be a fairly important transfer point between the tunnels. The proposed route geometry in line with the Technical Standards [6] and the location of the stops allowed for the maximum train speed of $60 \mathrm{~km} / \mathrm{h}$, which is an acceptable value from the point of view of traffic flow. The locations of the new stops coincide with the location of the traffic generators shown in Figure 3. The reconstruction of the Świebodzki Railway Station from the headend to the transit station will enable convenient routing of tunnels through the city center. Thanks to such routing of the new routes, 9 out of 11 traffic generators marked in Figure $\mathbf{3}$ were connected using two routes with a slight elongation. Additionally, such routing of tunnels will enable the addition of a tunnel in the north-south relation from the Nadodrze Railway Station to the Main Railway Station with the tangential connection of the tunnels on Plac Społeczny and the possibility of its further extension to the southern parts of the city. 


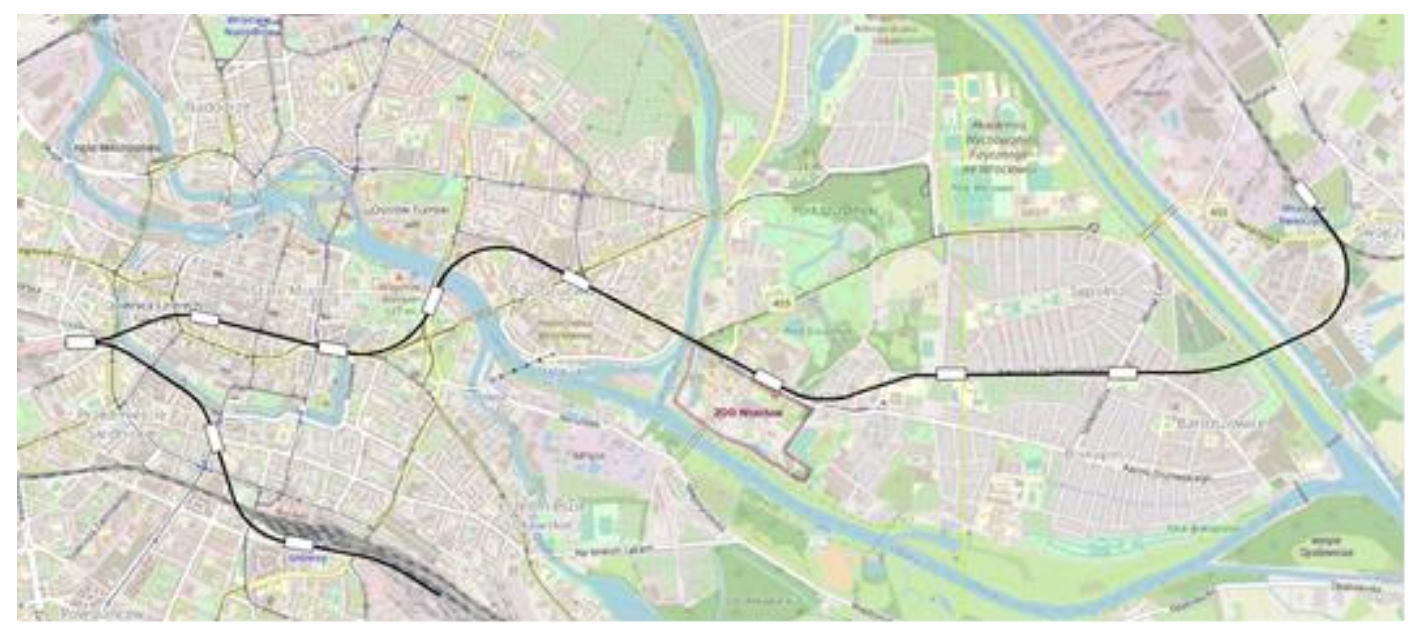

4. The proposed route of new cross-city routes Source: own study based on [5]

\section{Summary}

The article proposes the construction of new cross-city routes in Wrocław in order to create an efficiently functioning urban high-speed rail network with an agglomeration range. One of the most important advantages of creating new sections is the reduction of travel time to the center from the suburbs. This is an important point, especially for those traveling through the city center during rush hour. Figure $\mathbf{5}$ shows the approximate travel times along the central section between stations.

\begin{tabular}{|c|c|c|c|c|c|c|c|c|c|}
\hline $\begin{array}{l}\text { do stacji: } \\
\text { (w minutach) }\end{array}$ & 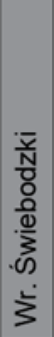 & 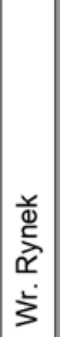 & 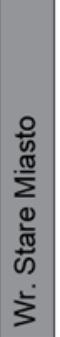 & 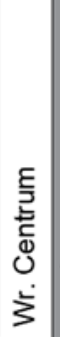 & 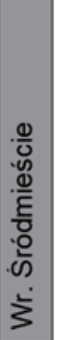 & 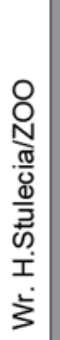 & 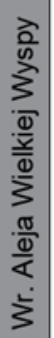 & $\begin{array}{l}\frac{c}{0} \\
\frac{2}{2} \\
\frac{0}{0} \\
\dot{5}\end{array}$ & 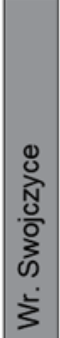 \\
\hline Wr. Świebodzki & $X$ & 1 & 3 & 5 & 7 & 10 & 12 & 14 & 17 \\
\hline Wr. Rynek & 1 & X & 2 & 4 & 6 & 9 & 11 & 13 & 16 \\
\hline Wr. Stare Miasto & 3 & 2 & $X$ & 2 & 4 & 7 & 9 & 11 & 14 \\
\hline Wr. Centrum & 5 & 4 & 2 & $X$ & 2 & 5 & 7 & 9 & 12 \\
\hline Wr. Śródmieście & 7 & 6 & 4 & 2 & X & 3 & 5 & 7 & 10 \\
\hline Wr. H.Stulecia/ZOO & 10 & 9 & 7 & 5 & 3 & X & 2 & 4 & 7 \\
\hline Wr. Aleja Wielkiej Wyspy & 12 & 11 & 9 & 7 & 5 & 2 & X & 2 & 5 \\
\hline Wr. Biskupin & 14 & 13 & 11 & 9 & 7 & 4 & 2 & $X$ & 3 \\
\hline Wr. Swojczyce & 17 & 16 & 14 & 12 & 10 & 7 & 5 & 3 & \\
\hline
\end{tabular}

5. Approximate journey times between the stops in the tunnel connecting the Świebodzki railway station with the Wrocław Swojczyce station

Source: [2]

The Wrocław Świebodzki - Wrocław Swojczyce route will be covered by the train in approx. 17 minutes, which is an impossible result with the current network of connections. With the length of the connection, these discrepancies are increasing in favor of the rail connections. It is also worth noting that the train travel time is constant and does not depend on the traffic volume, which cannot be said about tram or bus transport. It may contribute to 
the increase in the popularity of rail transport in the daily journeys of residents. Thus, a more ecological means of transport will be selected, which is in line with the city's current policy related to the Sustainable Mobility Policy [3, 11]. In addition to shortening the travel time to the center, the advantages include: connecting the Świebodzki Railway Station with the Main Railway Station, no need to run LRT trains on the railway flyover, a rapid increase in capacity in the center, and bringing the railway network closer to the largest traffic generators in the city. The example of the S-Bahn in Munich shows that with a carefully designed network, it is possible to obtain large passenger flows on the urban high-speed rail network. Failure to undertake serious changes aimed at improving the quality of transport in the city, with the simultaneous development of peripheral areas will only aggravate the problem of transport in the city. The proposed new lines are only one of the solutions, unfortunately also one of the most expensive. Therefore, it is possible to consider a more economical solution, but as effective as the above-described routes.

\section{Source materials}

[1] Korolkiewcz, Gisterek, Filar, Knapik, „Centrum Świebodzkie - nowe centrum Wrocławia”. Wstępna koncepcja dla PKP S.A. i UM Wrocławia zagospodarowania przestrzennego terenów w rejonie Dworca Świebodzkiego.

[2] Korzeń M. „Koncepcja tunelu dla SKM we Wrocławiu”. Praca dyplomowa magisterska, Politechnika Wrocławska, $2021 \mathrm{r}$.

[3] „Plan Zrównoważonego Rozwoju Publicznego Transportu Zbiorowego Wrocławia”, Wrocław, listopad 2016, https:/www.wroclaw.pl/strategia-rozwoju-wroclawia2030/files/plan-transportowy/Plan_transportowy_Wroclawia_2016-2022.pdf

[4] Podkład mapowy: https://www.openrailwaymap.org/

[5] Podkład mapowy: https://www.openstreetmap.org/\#map=13/51.1161/17.0342

[6] Standardy Techniczne. Szczegółowe techniczne dla modernizacji lub budowy linii kolejowych do prędkości $\mathrm{V}_{\max } \leq 200 \mathrm{~km} / \mathrm{h}$ (dla taboru konwencjonalnego)/ $250 \mathrm{~km} / \mathrm{h}$ (dla taboru z wychylnym pudłem).

[7] Strona internetowa przewoźnika S-Bahn w Monachium, https://www.2.stammstreckemuenchen.de/

[8] Strona internetowa przewoźnika S-Bahn w Monachium, https://www.s-bahnmuenchen.de/

[9] System Informacji przestrzennej Wrocławia, https://geoportal.wroclaw.pl/

[10] Uchwała $\mathrm{Nr}$ XLV/1366/10 Rady Miejskiej Wrocławia z dnia 21 stycznia $2010 \mathrm{r}$. zatytułowana „W sprawie uchwalenia miejscowego planu zagospodarowania przestrzennego dla fragmentu zespołu urbanistycznego Centrum w rejonie Placu Społecznego we Wrocławiu”. Biuletyn Urzędowy RMW z 2010 r., poz. 928. http://uchwaly.um.wroc.pl/uchwala.aspx?numer=XLV/1366/10

[11] Uchwała Nr XLVIII/1169/13 Rady Miejskiej Wrocławia z dnia 19 września 2013 r. zatytułowana „W sprawie wrocławskiej polityki mobilności”. Biuletyn Urzędowy RMW z 2013 r., poz. 354. http://uchwaly.um.wroc.pl/uchwala.aspx?numer=XLVIII $/ 1169 / 13$ 